\title{
SOIL COMPACTION AND THE STABILITY OF LEVEES OF AQUACULTURE PONDS
}

\author{
Esner R. S. Magalhães ${ }^{1 *}$, Carlos E. de C. Freitas' ${ }^{1}$, Afrânio F. Neves Junior ${ }^{2}$, \\ Francisco C. da Silva Filho ${ }^{3}$
}

\begin{abstract}
$1^{1 *}$ Corresponding author. Universidade Federal do Amazonas/ Manaus - AM, Brasil. Departamento de Ciências Pesqueiras. E-mail: esnermagalhaes@gmail.com | ORCID ID: 0000-0002-6623-0015
\end{abstract}

\section{KEYWORDS}

aquaculture, fish farming, soils, levees, stability.

\begin{abstract}
The aim of this work was to evaluate the effects of variations in soil compaction on the stability of the slope embankments of fish farms used in aquaculture. Computational modeling was performed using the RocScience Slide 6.0 program, simulating filling scenarios, fast lowering and stationary regimes for the full operation of the fish farms. The data used in these simulations were obtained from soil characterization tests in the laboratory. The geometry of the levees, the inclination of the slopes and the crest width and height, also necessary for modeling, were obtained from field data and technical projects. The modeling generated a safety factor (SF) for the upstream and downstream slopes of the levees, considering different upstream slopes, for three types of levees (L1, L2 and L3). The results have shown that the variation in soil compaction, regardless of the upstream inclination of the slopes, maintains the stability of the levee slopes, as it generated safety factors above the acceptable minimum $(\geq 1.5)$. Decreasing the speed of lowering the water column in the fish farm does not compromise the stability of the embankments of the levees. The construction of superficial pond levees for aquaculture can be performed at points below the optimum water contents for compaction since the stabilization of these structures showed SF values above the minimum required.
\end{abstract}

\section{INTRODUCTION}

With the increasing demand for food worldwide, the production of fish in captivity has been growing in recent decades. A number of underdeveloped and developing countries, such as India, Vietnam, Indonesia, Bangladesh, Thailand, Egypt, Myanmar, the Philippines, Peru, Colombia, Nicaragua and Brazil, have been engaged in aquaculture activities in tanks and fish farms for decades (Hayek \& Boyd, 1994; Alvarez-Lajonchèrea \& Pérez-Roab, 2012). In Brazil, aquaculture produced 580,070 tons of animals, valued at $\mathrm{R} \$ 4.2$ billion, with $77.32 \%$ of it, specifically fish (IBGE, 2016). The North Region of Brazil leads the production, with approximately 149,745 tons, approximately $29.5 \%$ of the national production (IBGE, 2016). The Amazon produced more than 20,000 tons, with $80 \%$ of this total coming from land and levee farms. These structures are preferred due to the availability of area and soils comprising high percentages of silt and clays, which facilitates water retention (Vale Júnior \& Souza, 2011; Oliveira, 2013;

IBGE, 2016). On the other hand, the advance in the construction of these structures has generated a series of geotechnical problems, as well as the lack of stabilization, mainly during the operations phase of the fish farm levees since they are used for the transit of vehicles during the activities (Kubitza \& Onu, 2003). The engineering of the aquaculture projects did not follow the technological progress observed in the production processes, both in the understanding of the soil behavior and in the availability of computational platforms for the calculation of the stability of the earth. The mass limiting balance method, which consists of the determination of an active soil mass delimited by a circular, polygonal or any other form of rupture surface, considering parameters of soil resistance and water percolation in earthworks, has not yet been applied since most of the studies in the area of aquaculture have always focused on the productive sector (Bishop,

\footnotetext{
${ }^{1}$ Universidade Federal do Amazonas/ Manaus - AM, Brasil. Departamento de Ciências Pesqueiras.

${ }^{2}$ Universidade Federal do Amazonas/ Manaus - AM, Brasil. Centro de Educação a Distância - CED.

${ }^{3}$ Universidade Federal do Ceará/ Fortaleza - CE, Brasil. Centro de Tecnologia.

Received in: 8-22-2018

Accepted in: 6-18-2019
} 
1955; Spencer, 1967; Gaioto, 1998; Paschoalin Filho, 2002; Trindade, 2008; Gerscovich, 2012).

The operation of a fish farm is dictated by the filling, lowering and stationary water column regimes responsible for the various changes in the behavior of the levees over time. Rapid lowering of the water column in earth dams built with homogeneous sections of soils causes upstream slope stabilization problems if the interstitial pressures remaining in the inner portion of the core are not dissipated, especially in structures constructed with finer soils. Therefore, aiming to better understand the stability of levees in aquaculture nurseries, the present work carried out computational modeling, simulating the construction of fish farm levees from data from laboratory tests of soil mechanics to generate a safety factor (SF) for these structural slopes in different periods of operation.

\section{MATERIAL AND METHODS}

The soil used in the laboratory tests was collected in April 2014 at the Farm "Ecology Pescados" (02 46'46.39" $\mathrm{S}$ and $59^{\circ} 21^{\prime} 55.61^{\prime} \mathrm{W}$ ), located at $\mathrm{km} 126$ of AM 010, in the municipality of Rio Preto da Eva, Amazonas, Brazil, using hoes, shovels and plastic pockets. The samples were stored in identified plastic bags and transported to the Aquaculture Engineering Laboratory of the Federal University of Amazonas in Manaus, where they were dried and broken to the point that they were suitable for laboratory tests. The granulometric characterization of the soil samples was carried out by the methods of thick sieving and sedimentation, following the NBR 7181/1984. To define the soil compaction curve, with the values of humidity (\%) and specific dry mass $\left(\mathrm{g} \mathrm{cm}^{-3}\right)$, Proctor soil compaction tests were performed with the use of a cylinder and small socket, applying compaction (P1, P2, P3, P4 and P5) with different moisture and specific dry mass characteristics (NBR 7182/1986) (Proctor, 1933). The analyses presented and used in the modeling of the scenarios depart from the characteristics of points P1 and P3 of this curve. Soil permeability tests, according to NBR $14545 / 2000$, were performed using variable load permeability to obtain a permeability coefficient (Ks $\left.\mathrm{cm} \mathrm{s}^{-1}\right)$, with specimens generated in the same humidity conditions (\%) and the maximum specific dry mass, obtained in the Proctor compaction tests, for points $\mathrm{P} 1$ and $\mathrm{P} 3$ of the Proctor compaction curve (Darcy, 1856; Proctor, 1933).

Aiming to define the circular break surface of the soil mass of the upstream and downstream slopes of the dams (Mohr, 1900), the resistance parameters of the soil samples (cohesion and friction angle) were obtained through direct shear tests (\%) and dry specific mass $\left(\mathrm{g} \mathrm{cm}^{-}\right.$ ${ }^{3}$ ) of the points P1 and P3 of the Proctor compaction curve. The specimens were submitted to individual loads with vertical stresses of 50,100 and $200 \mathrm{KPa}$ until the samples completely ruptured. The comparison of the shear stresses mobilized with the shear strength offered by the soil, considering different inclinations of the upstream and downstream slopes of the levees (Table 2), were applied by the limit-balance method, generating a safety factor (SF), with a minimum value of 1.5 (Slope Stability Manual, 1996) as follows:

$$
\begin{gathered}
F S=\tau \mathcal{R} / \tau \mathrm{M} \\
\mathrm{SF}=\text { Safety Factor; } \\
\tau \mathcal{R}=\text { Resistance tension, } \\
\tau \mathrm{M}=\text { Tension of mobilized shear }
\end{gathered}
$$

The modeling was performed with the use of the program Slide 6.0, developed in the University of Toronto by the RocScience enterprise in 2010. The variation in the values of the SF through the stability analyses and the transient regimes of filling, lowering and maintaining the water column, simulating the operation of the fish farms, are obtained for both the upstream slopes and the downstream slopes of the levees. The input data for the

\begin{tabular}{|c|c|c|c|}
\hline $\begin{array}{l}\text { Type of } \\
\text { analysis }\end{array}$ & $\begin{array}{l}\text { Simulation time } \\
\text { (days) }\end{array}$ & Used properties & Product generated \\
\hline Stability & 412 & $\begin{array}{l}\text { 1) cohesion; } \\
\text { 2) friction angle } \\
\text { 3) geometry of the levee } \\
\text { 4) dry mass }\end{array}$ & $\begin{array}{l}\text { 1) Safety factor (SF) of upstream and } \\
\text { downstream slopes }\end{array}$ \\
\hline Transitional & $\begin{array}{c}\text { Lowering }-7 \\
\text { Filling }-5 \\
\text { Stationary - } 400\end{array}$ & $\begin{array}{l}\text { 1) coefficient of permeability } \\
\text { 2) contour area (lateral perimeter of the } \\
\text { levee) } \\
\text { 3) contour conditions (height of water } \\
\text { column of the fish levee) }\end{array}$ & $\begin{array}{l}\text { 1) Safety factor (SF) for filling, lowering } \\
\text { and stationary regimes; } \\
\text { 2) Lines of water percolation in the levee } \\
\text { core. }\end{array}$ \\
\hline
\end{tabular}
computer program are presented in Tables 1 and 2.

TABLE 1. Analysis and input data for the generation of the results from the characteristics of the P1 and P3 of the Proctor compaction curve. 
TABLE 2. Levee geometry data (L1, L2 and L3) used as input data in the Slide 6.0 program.

\begin{tabular}{c|cccc|cc|cc}
\hline \multirow{2}{*}{ Levees } & \multicolumn{4}{|c|}{ General data } & \multicolumn{4}{c}{ Slope } \\
\cline { 2 - 8 } & $\begin{array}{c}\text { Height } \\
(\mathrm{m})\end{array}$ & Water Level $(\mathrm{m})$ & Free Edge $(\mathrm{m})$ & Ridge $(\mathrm{m})$ & $\begin{array}{c}\text { Unstream } \\
\text { Inclination } \\
(\mathrm{H}: \mathrm{V})\end{array}$ & Length $(\mathrm{m})$ & Inclination (H:V) & Length (m) \\
\hline L1 & 2.0 & 1.7 & 0.3 & 3.4 & $2: 1$ & 4.0 & $1: 1$ & 2.0 \\
L2 & 2.0 & 1.7 & 0.3 & 3.4 & $1.5: 1$ & 3.0 & $1: 1$ & 2.0 \\
L3 & 2.0 & 1.7 & 0.3 & 3.4 & $1: 1$ & 2.0 & $1: 1$ & 2.0 \\
\hline
\end{tabular}

* Inclination: $\mathrm{H}=$ Horizontal; $\mathrm{V}=$ Vertical.

\section{RESULTS AND DISCUSSION}

The granulometric analysis indicated a soil with $85 \%$ clay, $6 \%$ sand and $9 \%$ silt. (Figure 1 ). Soils that have a predominance of a single grain diameter in their composition are called poorly graded and are not suitable from the engineering point of view. In well-graded soils, the smaller particles occupy the voids left by the larger grains, thus creating a greater entanglement, resulting in less compressibility and greater resistance (Pinto, 2000).

Soils with clay percentages between 20 and $30 \%$ are considered excellent to avoid structural collapses in aquaculture fish farms (Villamil, 1990; Lawson, 1994; Rodriguez \& Victoria, 2001; Oliveira, 2013).

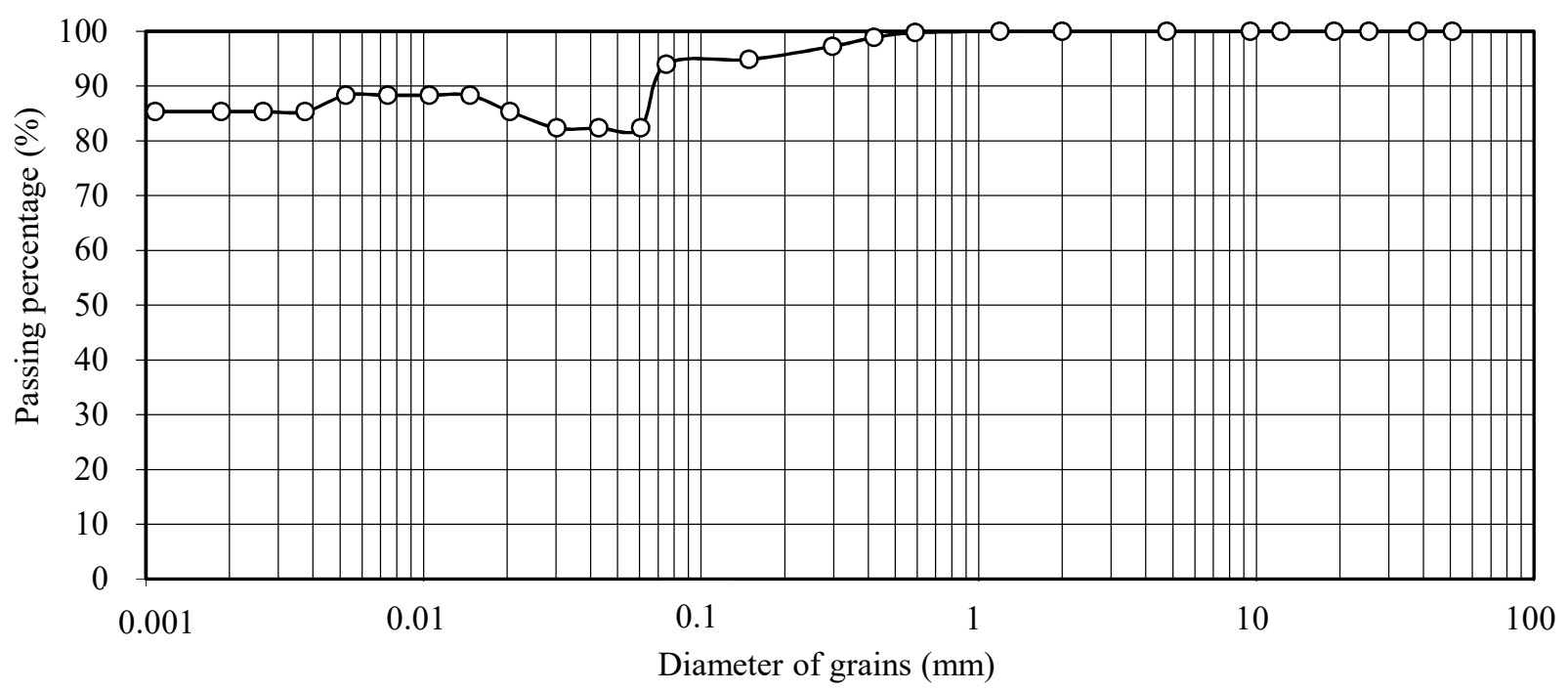

FIGURE 1. Grain size distribution data of the analyzed soil samples.

Considering only the retention of water inside the fish farms, we can say that the high clay percentages found in this soil decrease the rates of infiltration, minimizing the costs of water pumping to replace the losses by infiltration and evaporation (Figure 1). This implies the need to consider laboratory analyses, such as conclusive data on the granulometric distribution of the soils not based only on a simple visual or tactile examination, to determine soil properties, as proposed by Lawson (1994) and Oliveira (2013).

The predominance of fine-grained soil gradation should not be based solely on the percentages of silt and clay, making it necessary to understand the clay activity obtained through the limits of consistency, such as liquidity limit LL. This information helps in deciding the variation in the soils used in the upstream and downstream slopes and, especially, in relation to the built area (Casagrande, 1948; Eica, 1991; Pinto, 2000).

The compaction analysis in $\mathrm{P} 1$ presented a humidity of $31 \%$ and a specific dry mass of $1.11 \mathrm{~g} \mathrm{~cm}^{-3}$. For P3, these values were $35 \%$ and $1.33 \mathrm{~g} \mathrm{~cm}^{-3}$, which are considered the optimum compaction point of the experiment (Figure 2). The increase in the specific dry mass of P1 compared to P3 is a pattern that occurs in the Proctor compaction tests due to the addition of water during the test, which acts as a lubricant, facilitating the mobilization of the particles, causing them to slip one over the other and tends to increase the sample density (Pinto, 2000; Das Braja, 2005).

Clay soils, within the range of 20 to $30 \%$ clay, when compacted at points below P3 (optimum compaction humidity), that is, at $\mathrm{P} 2$ and $\mathrm{P} 1$, tend to have a flocculated structure due to the low humidity content, generating diffuse layers of incomplete ions around the soil particles, 
facilitating the percolation of water (Lambe, 1958). When compacted with optimum humidity, an inverse behavior occurs because the diffuse layers around the soil particles expand, increasing the repulsion between the clay particles, producing a lower degree of flocculation and a higher specific dry mass since the lubrication process with the addition of water generates a more compact arrangement of the soil due to the elimination of air from the voids, thus becoming the point that generates the data to be applied in the field works (Figure 2) (Massad, 2010). After reaching P3 in the compaction test, the subsequent points in the Proctor curve can no longer expel air from the voids because the degree of saturation is already high and the air is occluded, that is, encased in water.

The average values of the permeability coefficient (Ks) were $1.10 \times 10^{-6} \mathrm{~cm} / \mathrm{s}$ for P1 and $2.20 \times 10^{-8} \mathrm{~cm} / \mathrm{s}$ for $\mathrm{P} 3$, considered low and with maintenance of the pore pressure in the bulk of the dams during operation, mainly for P3. Studies of soil samples at different humidities have shown that the permeability of compacted soils in drier branches of the compaction curve is higher than in humid places due to the flocculation of the particles, allowing a greater flow of water (Lambe, 1958).

Low permeability coefficients indicate that voids in the soils are as small as the size of the particles in the soil samples, as evidenced by the high clay content (Figure 1) (Terzaghi et al., 1996, Massad, 2010; Pinto, 2000; Marinho, 2005). During the permeability tests in P3, we observed that the water level in the burette connected to the permeameter practically did not decrease, indicating low permeability, unlike that observed in P1. It is inevitable that water infiltrates the mass of pond levees, and it is even desirable if we consider the issues of dissipation of the porosity between the soil particles, which can have a great effect on the stability of the slopes of these structures (Sandroni, 2006).

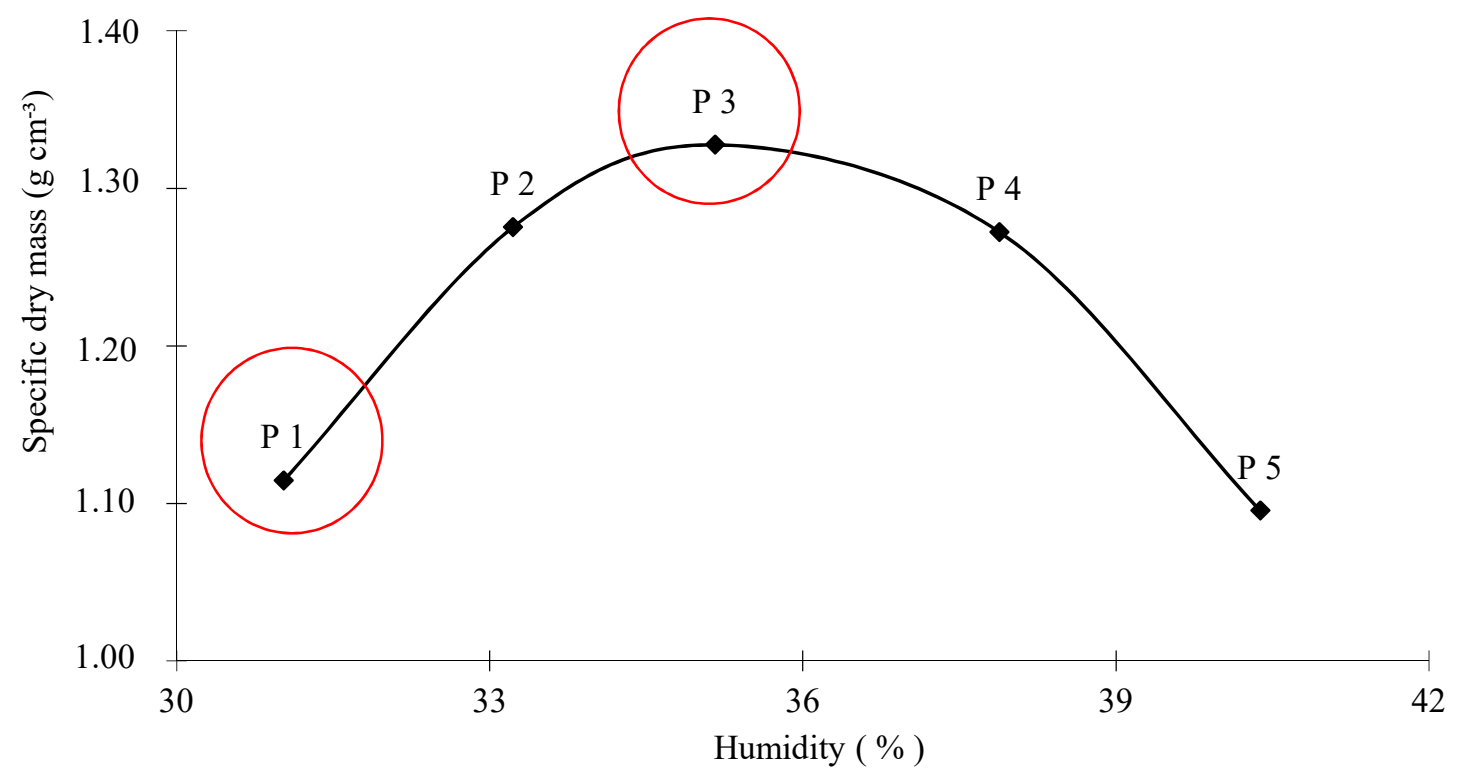

FIGURE 2. Proctor compaction curve with values of specific dry mass and humidity, indicating the points P1 (driest branch) and P3 (optimal point), used as the basis for the modeled scenarios.

The direct shear indicated differences in the cohesion values and the angle of friction between P1 and $\mathrm{P} 3$, especially in the observed cohesion, since it is data that provide a better understanding about the resistance of the soils, especially in those with high levels of clay (Table 3) (Massad, 2010).

The differences between the cohesion and the friction angle values identified for $\mathrm{P} 1$ and $\mathrm{P} 3$ showed that the variation in the humidity has a wide interference since it increases the cohesion due to its rise and reduces the angle of friction of the soil particles due to the greater friction between them (P3) (Taylor, 1948; Carvalho \& Paschoalin Filho, 2004; Craig, 2013). The resistance, cohesion and angle of friction data are very important in the analysis of small earthen dams in the final construction situations, during the operation and in the lowering of the reservoir water level (Pinto, 2000; Trindade, 2008). As there are no studies applied directly to pond dams, but since levees and embankments are structures with differences only in size and function, these analyses become essential in relation to the lifespan and stability of the structures throughout the operation.
During the fish farm's filling regime, the computational analyses of the water percolation line formed in the levees indicated that the largest variations in the three dams analyzed were for P1, possibly because it is the point with the highest permeability coefficient (Table 2) (Figures $3-5)$. In relation to the values of the safety factor, the lowest values occurred in all the downstream slopes of the P1 levees, but still above the acceptable minimum $(\geq 1.5)$ (Figures 3C, 4C and 5C) (Spencer, 1973).

The variation in the water percolation lines and the safety factor have a direct relation with the hydraulic and soil resistance parameters due to the greater number of voids between the soil grains, which facilitates the movement of the water inside the core of the structures. However, even with all the characteristics presented in this simulation, it is certain that the filling system of fish farms, considered as the first phase of operation of the levee, did not show any sudden variation that indicates instability of the slopes in the simulated conditions since the arcs indicated in the slopes of the figures below translated a favorable scenario for the three simulated levees. 
TABLE 3. Hydraulic and soil resistance parameters for P1 and P3 obtained in the slow direct shear tests.

\begin{tabular}{c|ccccc}
\hline Spots & Cohesion (Kpa) & Friction angle (graus) & Specific dry mass $\left(\mathrm{g} \mathrm{cm}^{-3}\right)$ & Optimal Humidity $(\%)$ & Permeability $\left(\mathrm{cm} / \mathrm{s}^{-1}\right)$ \\
\hline P1 & 9.28 & 32.59 & 1.11 & 31 & $1.10 \mathrm{e}-6$ \\
P3 & 38.96 & 20.69 & 1.33 & 35 & $2.20 \mathrm{e}-8$ \\
\hline
\end{tabular}

With the natural formation of the percolation line in the core of the levees, the main fear should be the promotion of internal erosion due to the flow of water with the potential to carry solid particles of the structure, generating voids and pipes for water passage, leading to a decrease in the resistance parameters of the work and to collapse (Sandroni, 2006). Considering the Mohr-Coulomb criteria, the rupture that can occur in a slope of a fish farm embankment should be evaluated from the internal tensions in the core of the levee, defined directly by the shear strength that the soils present. That is, if the structure shows no signs of rupture, identified by the minimum values of the safety factor, this indicates that the material used in the construction of the levees is able to withstand the loads imposed on it. We do not yet know the percentage, in terms of slope rupture, that percolation of water may represent to the dams constructed with materials different from those surveyed in this study.
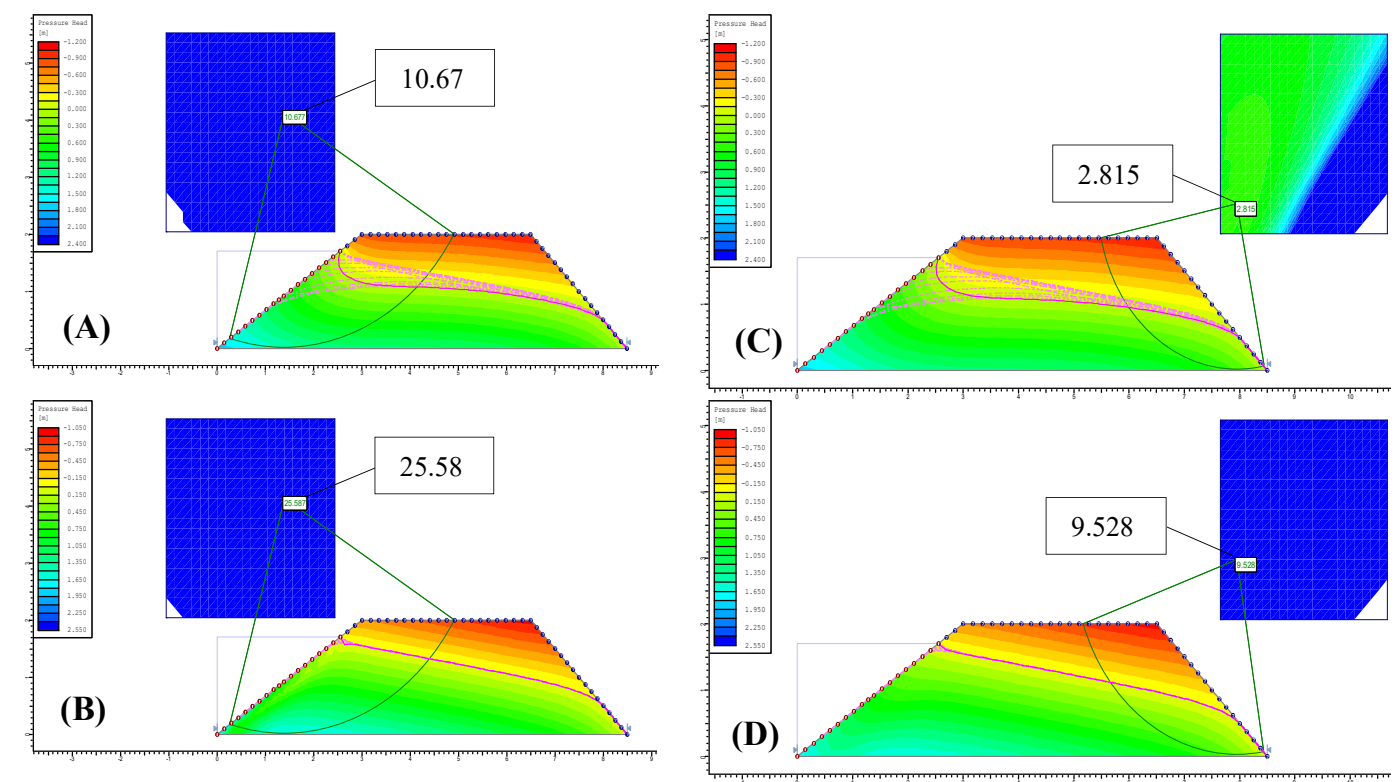

FIGURE 3. Slope stability analysis, water flow network and the possible rupture surface (arc line) with the safety factor (SF) of the upstream slopes (A) P1 (B) P3 and downstream (C) P1 and (D) P3 from Levee 1 (L1) in the filling condition, for points one and three (P1 and P3).
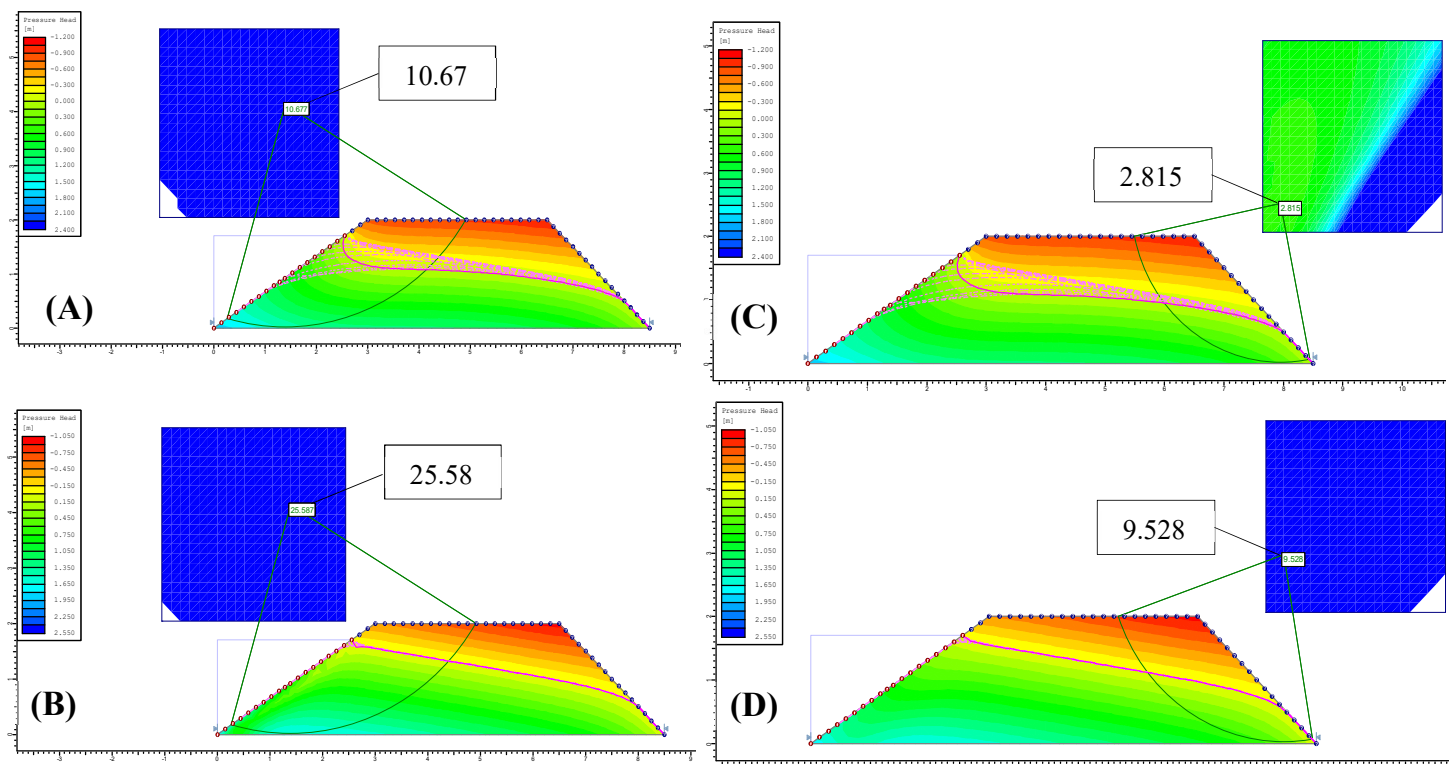

FIGURE 4. Slope stability analysis, water flow network and the possible rupture surface (arc line) with the safety factor (SF) of upstream slopes (A) P1 (B) P3 and downstream (C) P1 and (D) P3 from Levee 2 (L2) in the filling condition for points one and three (P1 and P3) 


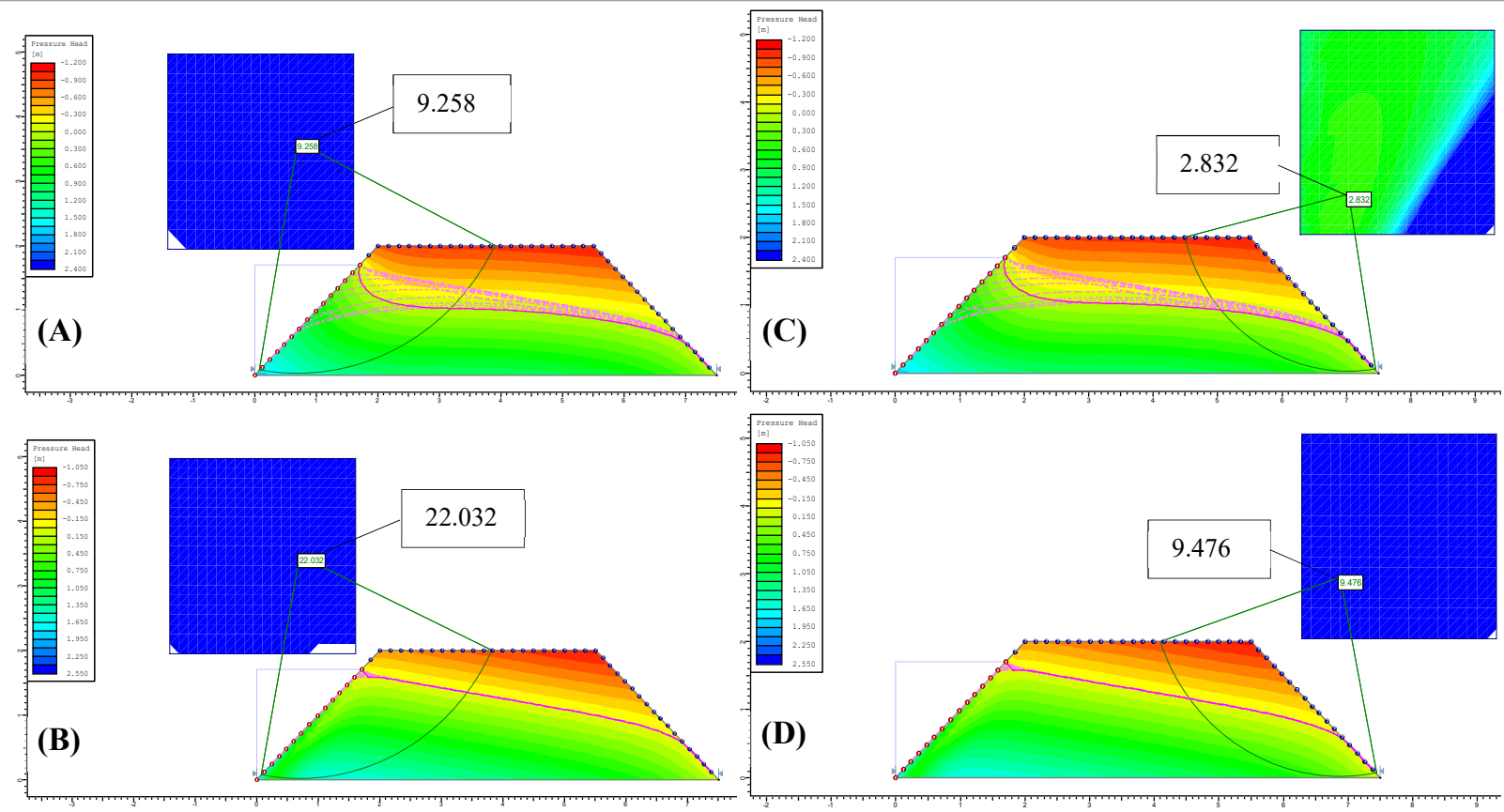

FIGURE 5. Stability analysis, water flow network and the possible rupture surface (arc line) with the safety factor (SF) of upstream slopes (A) P1 (B) P3 and downstream (C) P1 and (D) P3 from Levee 3 (L3) in the filling condition, for points one and three (P1 and P3).

In the fast lowering condition, the values of the safety factor were higher in the upstream slope at P3, decreasing from 10.5 to 9.1 from L1 to L3 (Figures 6B, $7 \mathrm{~B}$ and $8 \mathrm{~B})$. In relation to the $\mathrm{P} 1$ levees, these values were almost three times smaller when compared to those of the P3 levees but also followed a decreasing order from D1 to D3 with a safety factor varying from 3.2 to 2.6. All values remained above the required minimum, ruling out any possibility of impending slope breakage (Figures 6A, 7A and 8A).

The process of lowering the water level of a fish farm during the stages of productive management, either in reduction to the appropriate level for expenditure or in complete emptying for cleaning, is one of the actions that can promote the instability of the levee, especially the slope with the full pressure in the water column. In this process, it is fundamental to understand the variations in soil resistance, and the occurrence of dissipation of the pore pressures that remain inside the dam during this lowering regime (Kerkes \& Fasset, 2006).

During the seven days of lowering, the water percolation lines that formed inside the levees did not follow the speed of the lowering of the water column of the nursery, except for the P1 levees to a certain extent, maintaining and then stagnating, indicating that the pore pressure remains constant in the structure, characterizing the regime as slow since it does not accompany the descent of the water level of the fish farm (Figures 6 to 8). These results indicate that structures constructed with these characteristics should not be left unused for a long time since the rupture is conditioned by the existing pore pressure that reduces the resistance of the soil, reducing the effective tension, and stabilized with fast water filling of the fish farm. The resumption of the dam prevents internal decompression and maintains the tensions in balance (Sandroni, 2006). 

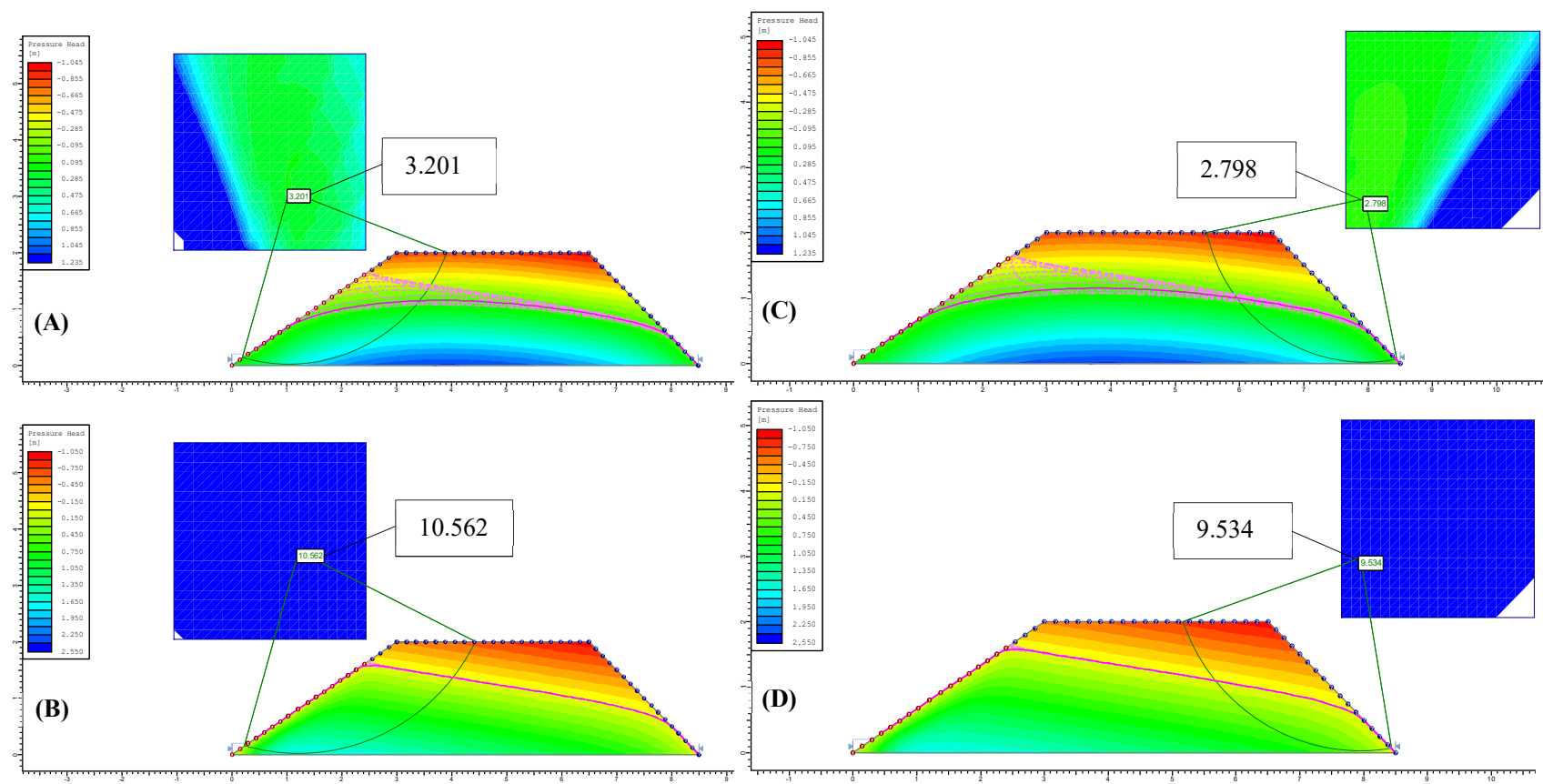

FIGURE 6. Stability analysis, water flow network and the possible rupture surface (arc line) with the safety factor (SF) of upstream slopes (A) P1 (B) P3 and downstream (C) P1 and (D) P3 from Levee 1 (L1) in the final fast-lowering condition for P1 and P3.
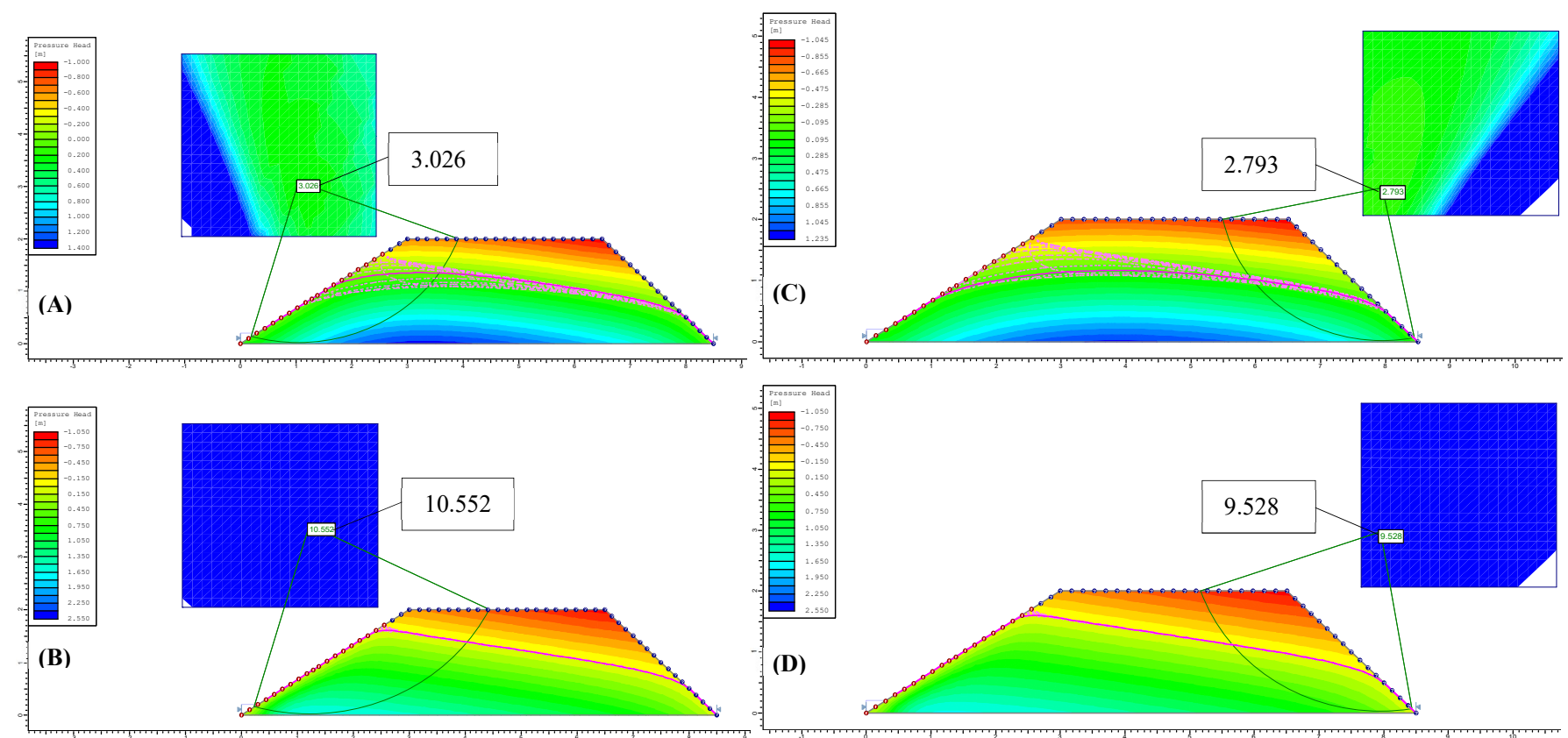

FIGURE 7. Stability analysis, flow network and the possible rupture surface (arc line) with the safety factor (SF) of the upstream slopes (A) P1 (B) P3 and downstream (C) P1 and (D) P3 of Levee 2 (L2) in the final fast lowering condition for P1 and P3. 


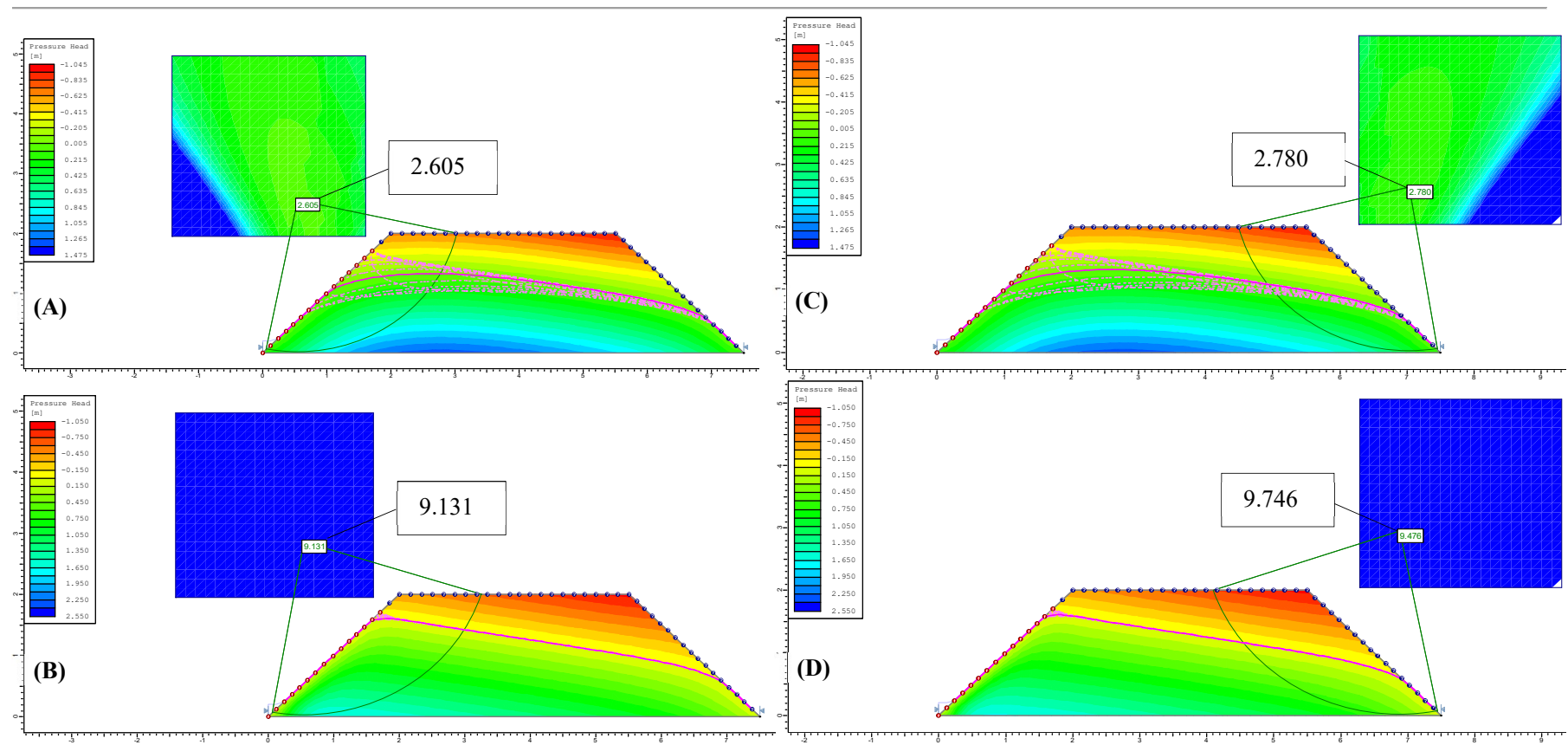

FIGURE 8. Stability analysis, flow network and the possible rupture surface (arc line) with the safety factor (FS) of the upstream slopes (A) P1 (B) P3 and downstream (C) P1 and (D) P3 from Levee 3 (L3) in the final fast lowering condition, for P1 and P3.

After the simulation of 400 days in operation, the values of the safety factor observed in the steady state also decreased from L1 to L3, being higher in P3, ranging from 25.4 to 21.8 in the upstream slopes of the levees (Figure 9B, $10 \mathrm{~B}$ and 11B). The scenario for $\mathrm{P} 1$ presented lower upstream SF values for the levees but remained above the minimum acceptable range (Figure 9A, 10A and 11A). For the downstream slopes of the levees, the SF values also followed a decreasing order from L1 to L3 at the two simulated points, approaching the acceptable minimum only at P1, which implies an imminent collapse in the portion analyzed (Figure 9CD and 11CD).

The downstream slope deserves more care during this regime since the compression of the water column of the fish farm is maintained on the upstream slope, thus maintaining stable internal stresses, excluding the risks of rupture. On the other hand, due to the long period in operation, the water percolation in the mass continues in the direction of the downstream slope, with the tensions acting in this direction, being able to cause internal erosion if there is a high loss of soil resistance, carrying particles and, with this, leading the structure to collapse (Massad, 2010; Craig, 2013). During this regime, greater control of the internal percolation of water is required to prevent its leaking on the downstream slope faces.

To study the longevity of the dams, after 400 days of operation in the stationary regime, a new fast transition was simulated with a duration of three days. The fish farms remained empty for 15 days, which is considered an average period for the cleaning and preparation phases of the structures for a new production cycle. We observed that in these conditions, the safety factor remained high for P1 and P3 in all levees, indicating that such structures remain outside the zone of collapse for longer periods. 

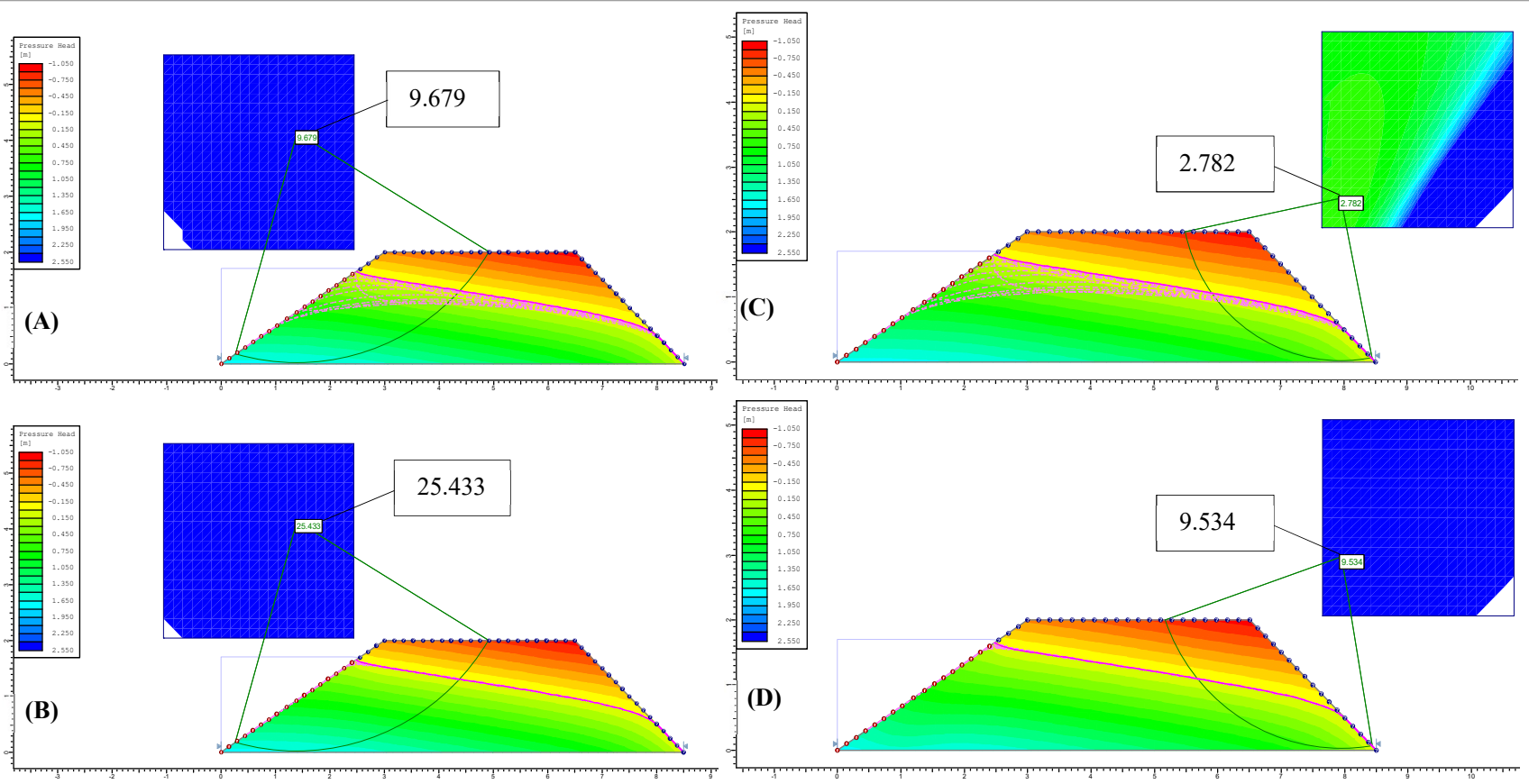

FIGURE 9. Stability analysis, flow network and the possible rupture surface (arc line) with the safety factor (SF) of the upstream slopes (A) P1 (B) P3 and downstream (C) P1 and (D) P3 from Levee 1 (L1) in the stationary condition, for P1 and P3.
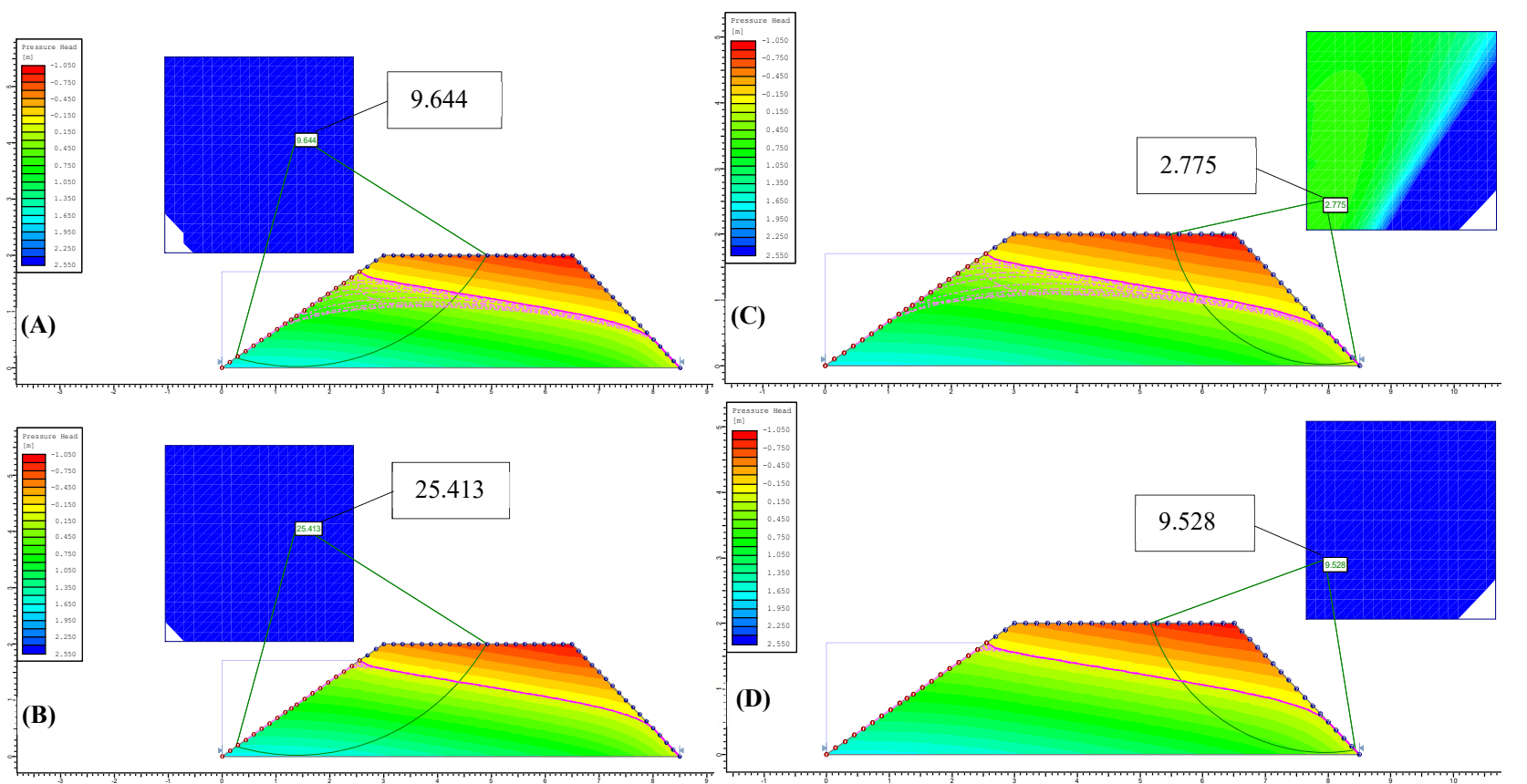

FIGURE 10. Stability analysis, flow network and the possible rupture surface (arc line) with the safety factor (SF) of the upstream slopes (A) P1 (B) P3 and downstream (C) P1 and (D) P3 from Levee 2 (L2) in the stationary condition, for P1 and P3. 

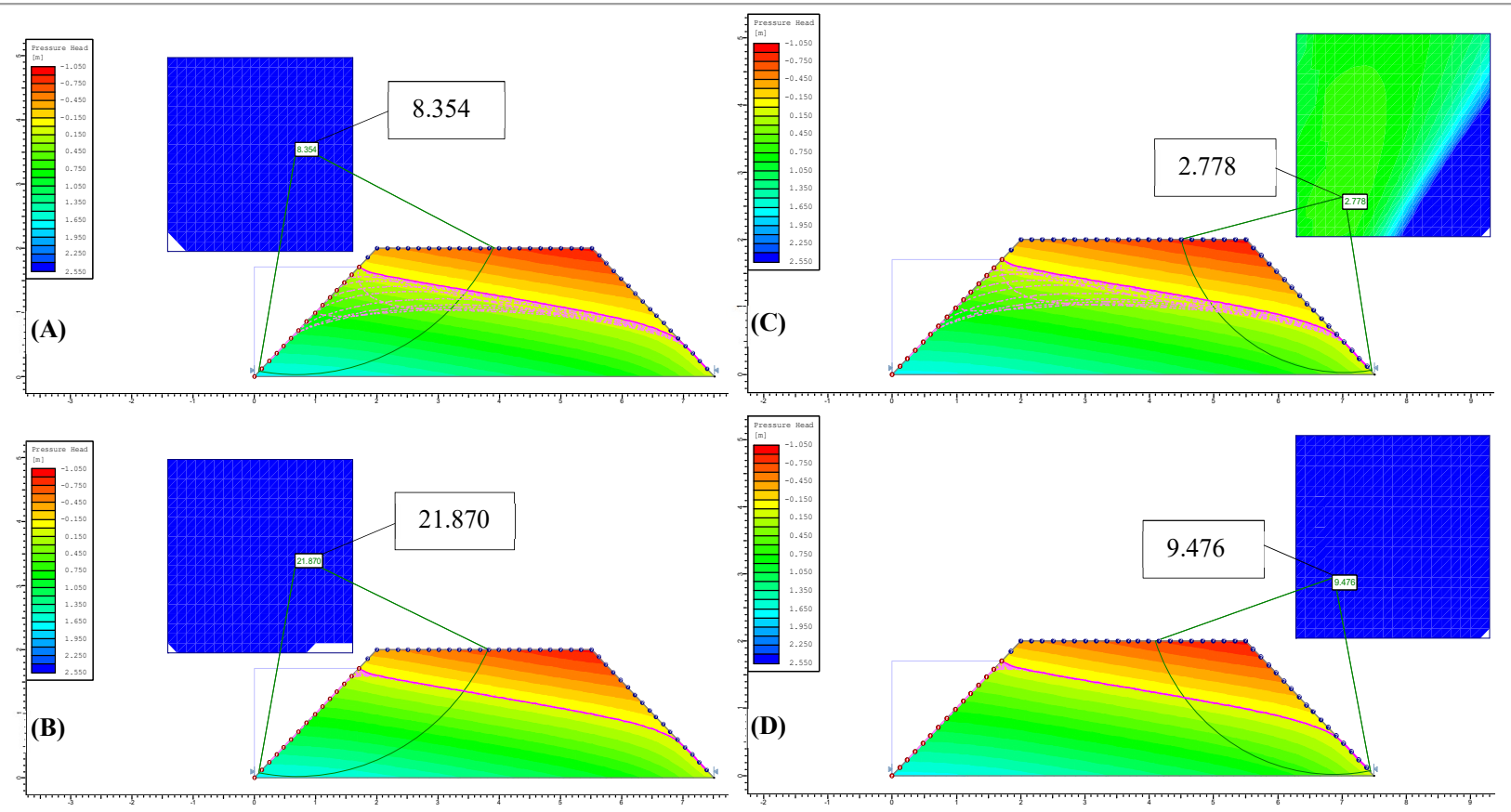

FIGURE 11. Stability analysis, flow network and the possible rupture surface (arc line) with the safety factor (SF) of upstream slopes (A) P1 (B) P3 and downstream (C) P1 and (D) P3 from Levee 3 (L3) in the stationary condition for points one and three (P1 and P3).

Once we understand the effects of the filling, lowering and stationary regimes on the safety factor, we also try to understand the effects of variations in emptying velocities on the stability of the upstream and downstream slopes. We observed that the reduction in the emptying velocity (meters/day) indicates an increase in the safety factor of the upstream slope in all the levees. Considering only the perimeter of the dams, which varied according to the length of the upstream slope, we observed that there was a reduction in the safety factor from L1 to L3, that is, smaller perimeters generate lower values that are directly related to the smaller proportions used for the upstream slopes of the simulated levees (Table 4). Regardless of the inclination of the upstream slope and the simulated point, either P1 or P3, all dams remained above the acceptable minimum, far from any possibility of slope rupture. It is expected that the increase in the upstream slope of a dam causes an increase in the operating tensions, which may result in its rupture (Guidicini \& Nieble, 1983). 
TABLE 4. Time and velocity of emptying L1 ponds (2:1 and 1:1), L2 (1.5:1 and 1:1) and L3 (1:1 and 1:1) upstream and downstream, indicating the variation in the safety factor (SF) under the conditions of P1 and P3.

\begin{tabular}{|c|c|c|c|c|c|}
\hline \multirow{3}{*}{$\begin{array}{l}\text { Fish Pond } \\
\text { emptying (days) }\end{array}$} & \multirow{3}{*}{ Speed (m/day) } & \multicolumn{4}{|c|}{$\mathrm{SF}(\mathrm{L} 1)$} \\
\hline & & \multicolumn{2}{|c|}{ Upstream } & \multicolumn{2}{|c|}{ Downstream } \\
\hline & & P1 & P3 & P1 & P3 \\
\hline 1 & 1.70 & 2.88 & 10.47 & 2.78 & 9.53 \\
\hline 2 & 0.75 & 3.07 & 10.50 & 2.78 & 9.53 \\
\hline 3 & 0.56 & 3.11 & 10.51 & 2.78 & 9.53 \\
\hline 4 & 0.43 & 3.11 & 10.51 & 2.78 & 9.53 \\
\hline 5 & 0.34 & 3.13 & 10.52 & 2.79 & 9.53 \\
\hline 6 & 0.28 & 3.18 & 10.54 & 2.79 & 9.53 \\
\hline 7 & 0.24 & 3.20 & 10.54 & 2.79 & 9.53 \\
\hline \multirow{3}{*}{$\begin{array}{c}\text { Fish Pond } \\
\text { emptying (days) }\end{array}$} & \multirow{3}{*}{ Speed (m/day) } & \multicolumn{4}{|c|}{ SF (L2) } \\
\hline & & \multicolumn{2}{|c|}{ Upstream } & \multicolumn{2}{|c|}{ Downstream } \\
\hline & & P1 & P3 & P1 & P3 \\
\hline 1 & 1.70 & 2.86 & 10.47 & 2.77 & 9.53 \\
\hline 2 & 0.75 & 3.07 & 10.49 & 2.77 & 9.53 \\
\hline 3 & 0.56 & 3.10 & 10.49 & 2.77 & 9.53 \\
\hline 4 & 0.43 & 3.10 & 10.50 & 2.78 & 9.53 \\
\hline 5 & 0.34 & 3.12 & 10.50 & 2.78 & 9.53 \\
\hline 6 & 0.28 & 3.17 & 10.51 & 2.79 & 9.53 \\
\hline 7 & 0.24 & 3.19 & 10.51 & 2.79 & 9.53 \\
\hline \multirow{3}{*}{$\begin{array}{c}\text { Fish Pond } \\
\text { emptying (days) }\end{array}$} & \multirow{3}{*}{ Speed (m/day) } & \multicolumn{4}{|c|}{ SF (L3) } \\
\hline & & \multicolumn{2}{|c|}{ Upstream } & \multicolumn{2}{|c|}{ Downstream } \\
\hline & & P1 & P3 & P1 & P3 \\
\hline 1 & 1.70 & 2.46 & 9.00 & 2.77 & 9.48 \\
\hline 2 & 0.75 & 2.56 & 9.02 & 2.78 & 9.48 \\
\hline 3 & 0.56 & 2.61 & 9.02 & 2.78 & 9.48 \\
\hline 4 & 0.43 & 2.65 & 9.02 & 2.78 & 9.48 \\
\hline 5 & 0.34 & 2.68 & 9.04 & 2.79 & 9.48 \\
\hline 6 & 0.28 & 2.73 & 9.04 & 2.80 & 9.48 \\
\hline 7 & 0.24 & 2.72 & 9.05 & 2.80 & 9.48 \\
\hline
\end{tabular}

\section{CONCLUSIONS}

The fish farm water column filling, lowering and stationary regimes do not promote critical situations of upstream and downstream slope disruption;

The increase in the speed of lowering the water column of the fish farms does not make the safety factor of the upstream and downstream slopes critical;
The variation in the upstream slopes of the levees does not promote loss of stability to the structures;

Levees constructed with clay material, with percentages within what was found in this study, can be compacted with humidity of $\mathrm{P} 2$ of the Proctor compaction curve because they have acceptable safety factors and low permeabilities in their cores. 


\section{REFERENCES}

Alvarez-Lajonchèrea, L, Pérez-Roab R (2012) Site selection for tropical marine fish hatchery and its application in the Caribbean coast of Nicaragua. Aquacultural Engineering 46(2012):10-17.

Bishop AW (1955) The use of the slip Circle in the Stability Analisys of Earth Slopes. Géotéchnique 5:7-17.

Carvalho D, Paschoalin Filho JA (2004) Estudo da estabilidade de pequenas barragens de terra compactadas em três teores de umidade. Exacta 2:55-68.

Casagrande A (1948) Classification and identification of soils, Transactions ASCE 113:901-930.

Craig RF (2013) Mecânica dos solos/Soil Mechanics. Rio de Janeiro: LTC, 7ed. 362p.

Darcy H (1856) LesFountaines Publiques de laVille de Dijon. Paris, Dalmont.

Das Braja M (2005) Fundamentals of geotechnical engineering. Texas, Ed. Thompson, 2 ed. 566p.

Eica (1991) Memories of course on fish culture development. The Egyptian International Centre for Agriculture, 335p.

Gaioto N (1998) Barragens de terra e enrocamento. São Carlos, Escola de Engenharia de São Carlos, Universidade de São Paulo, 20p.

Gerscovich D (2012) Estabilidade de taludes. São Paulo, Oficina de textos.

Guidicini G, Nieble CM (1983) Estabilidade de taludes naturais e de escavação. São Paulo, Edgard Blücher.

Hayek BF, Boyd E (1994) Rating soil and water information for aquaculture. Aquacultural Engineering 13:115-128.

IBGE - Instituto Brasileiro de Geografia e Estatística (2016) Pesquisa da Pecuária Municipal. IBGE.

Kerkes DJ, Fasset JB (2006) Rapid drawdown in drainage channels with earthen side slopes. In: ASCE. Texas Section Springs Meeting, Proceedings... p19-22.

Kubitza F, Ono EA (2003) Construção de viveiros e de estruturas hidráulicas para o cultivo de peixes. Panorama da Aquicultura 13(75).

Lambe TW (1958) The Structure of Compacted Caly. Journal Soils Mechanics and Foundation Division, ASCE 84(SM2).

Lawson TB (1994) Fundamentals of aquacultural engineering. Includes bibliographical and index. Springer US.
Marinho FAM (2005) Os solos não saturados: aspectos teóricos, experimentais e aplicados. São Paulo, Universidade de São Paulo, 2005.

Massad F (2010) Obras de terra: curso básico de geotecnia. São Paulo, Oficina de textos, 2 ed.

Mohr O (1900) Welche Umstande Bedingen die Elastizitatsgrenze und den Bruch eines Materiales. Zeitschrift design: 195-200.

Oliveira PN (2013) Engenharia para aquicultura. Fortaleza, 361p.

Rocsience INC (2010) Slide Version 6.0 - 2D Limit Equilibrium Slope Stability Analysis. Toronto. Available: www.rocscience.com.

Paschoalin Filho JA (2002) Utilização de solo residual de diabásio como elemento de fundação e material de construção de aterros compactados para barragens de pequeno porte. Dissertação Mestrado em Construções, Campinas, Universidade de Campinas.

Pinto CS (2000) Curso básico de mecânica dos solos. São Paulo, Oficina de textos.

Proctor RR (1933) Fundamental principles of soil compaction. Engineering News Record 111(10):286-289.

Rodriguez H, Victoria M (2001) Fundamentos de aquicultura continental. Bogotá.

Sandroni S (2006) Curso básico sobre Barragens de Terra e enrocamento. COPPE/UFRJ.

Spencer E (1967) A method of analysis of the stability of embankments assuming parallel interslice forces.

Géotechnique 17:11-26.

Spencer E (1973) Thrust line criterion in embankment stability analysis. Géotechnique 23:85-100.

Taylor D (1948) Fundamentals of soil mechanics. New York, John Wiley \& Sons.

Terzaghi K, Peck RB, Mesri G (1996) Soil Mechanics in Engineering Practice. New York, John Wiley \& Sons.

Trindade TP (2008) Compactação dos solos: fundamentos teóricos e práticos. Viçosa, Ed: UFV, 95p.

Vale Júnior JF, Souza MIL (2011) Solos da Amazônia: etnopedologia e desenvolvimento sustentável. Revista Agro@mbiente 5(2):158-165.

Villamil VE (1990) Guía para construcción y manejo de estanques piscícolas. Bogotá, INDIRENA. 15p. 